\title{
Penggunaan Metode Survey, Question, Read, Recite, Review pada Pembelajaran Bahasa Inggris Siswa Sekolah Dasar
}

\author{
Ahmad Ghazali Samad ${ }^{1}$, Sri Wahyuni ${ }^{2}$ \\ 1,2 Universitas Puangrimaggalatung \\ e-mail: Anggazhalee@gmail.com
}

\begin{abstract}
This study aims to describe the increased activity and learning outcomes of elementary school English subjects through the use of Survey, Question, Read, Recite, Review (SQ3R) learning methods. This research was designed in two cycles, each cycle consisting of: Planning, Implementation, Observation, and Reflection. The research subjects were teachers and fifth grade students with 32 students, consisting of 22 women and 10 men. The results of the analysis of learning after applying the SQ3R model to students of SDN 213 Lapongkoda Regency, Wajo, namely in the pre-cycle stage of students completing a grade of sebanyak. 75 were 0 students with a percentage of incomplete $100 \%$. \% of learning completed with a value of $\geq 75$. In cycle II there was also an increase in the number of students completing the $\geq 75$ score of 28 students with a percentage of $88 \%$. So students who completed learning had increased from $68 \%$ to $88 \%$. Based on the results of the study, it can be concluded that the application of the SQ3R model is effective in improving English learning of elementary school students in Tempe District. After the research, it is suggested that the teacher should always supervise the class to continue to motivate students and provide guidance individually or in groups.
\end{abstract}

Keywords: SQ3R, Learning, English

Abstrak. Penelitian ini bertujuan mendeskripsikan peningkatan aktivitas dan hasil belajar mata pelajaran bahasa Inggris siswa SD melalui penggunaan metode belajar Survey, Question, Read, Recite, Review (SQ3R). Penelitian ini dirancang dalam dua siklus, tiap siklus terdiri dari :Perencanaan, Pelaksanaan, Pengamatan, dan Refleksi. Subjek penelitian adalah guru dan siswa kelas V dengan jumlah siswa 32 orang, terdiri atas 22 perempuan dan 10 laki-laki. Hasil analisis belajar setelah diterapkan model SQ3R pada siswa kelas SDN 213 Lapongkoda Kabupaten Wajo yaitu pada tahap prasiklus siswa yang tuntas dengan nilai $\geq 75$ sebanyak 0 siswa dengan persentase ketidak tuntasan 100\%.Pada siklus I hasilbelajar siswa meningkat, yaitu sebanyak 20 siswa dengan presentase 63\% tuntas belajar dengan nilai $\geq 75$.Pada siklus II juga terjadi peningkatan yaitu siswa yang tuntas dengan nilai $\geq 75$ sebanyak 28 siswa dengan persentase $88 \%$.Jadi siswa yang tuntas belajar mengalami peningkatan dari $68 \%$ sampai $88 \%$. Berdasarkan hasil penelitian, dapat disimpulkan bahwa penerapan model SQ3R ini efektif meningkatkan pembelajaran bahasa Inggris siswa SD di Kecamatan Tempe. Setelah adanya penelitian tersebut, disarankan guru hendaknya senantiasa mengawasi kelas untuk terus memotivasi siswa dan memberikan bimbingan secara individu maupun kelompok.

Kata kunci: SQ3R, Pembelajaran, Bahasa Inggris 


\section{PENDAHULUAN}

Tujuan pembelajaran merupakan salah satu aspek yang perlu di pertimbangkan dalam merencanakan pembelajaran, sebab segala kegiatan pembelajaran muaranya pada tercapainya tujuan tersebut (Uno, 2016:34). Oleh karena itu diperlukan keterampilan memilih dan menggunakan metode mengajar untuk diterapkan dalam sistem pembelajaran yang efektif sehingga akan membawa siswa kedalam situasi belajar yang bervariasi dan siswa terhindar dari situasi pengajaran yang membosankan.

Kegiatan belajar mengajar yang dilakukan oleh guru, untuk mencapai tujuan pembelajaran tidak dapat terpisahkan dengan metode yang digunakan. Dalam menggunakan suatu metode pembelajaran, tidak ada suatu metode pembelajaran yang lebih baik dari metode pembelajaran yang lain (Suharta,2013). Masing-masing metode pembelajaran mempunyai keunggulan dan kelemahan. Oleh karena itu guru harus bisa memilih metode pembelajaran yang sesuai dengan materi yang akan disampaikan.

Berdasarkan hasil observasi awal dengan guru mata pelajaran bahasa Inggris dan siswa di SDN 213 Lapongkoda diperoleh hasil bahwa kebanyakan siswa pasif dan banyak diam, hal ini disebabkan karena timbulnya rasa malu, kurang berani untuk bertanya dan menjawab pertanyaan maupun mengungkapkan pendapat. Menurut guru mata pelajaran bahasa Inggris, kesulitan yang dihadapi oleh siswa adalah dalam memahami bacaan, hal tersebut dapat dilihat saat mereka disuruh untuk membaca materi, setelah itu guru memberikan pertanyaan yang berkaitan dengan materi yang mereka baca, ternyata sebagian siswa tidak dapat menjawab pertanyaan dari guru. Hal tersebut menunjukkan bahwa mereka tidak memahami tentang apa yang mereka baca. Hal ini berakibat pada rendahnya hasil belajar.

Pelajaran bahasa Inggris adalah salah satu pelajaran yang pokok bahasannya berupa uraian teks, dimana kompetensi dasar yang dicapai adalah kemampuan mendeskripsikan pokok bahasan yang dibahas, sehingga diperlukan keterampilan siswa dalam membaca dan memahami materi. Untuk memahami materi tersebut diperlukan suatu cara agar dalam proses belajar baik di sekolah ataupun dirumah siswa dapat memahami tentang apa yang mereka baca sehingga berdampak pada peningkatan hasil belajar siswa, karena kualitas dan keberhasilan pembelajaran sangat dipengaruhi oleh kemampuan dan keterampilam guru dalam memilih dan menggunakan metode pembelajaran (Solihatin dan Raharjo, 2017:1).

Untuk mengatasi permasalahan yang ada, diperlukan suatu alternatif model pembelajaran yang lebih tepat dan menarik, yaitu dengan metode belajar Survey, Question, Read, Recite, dan Review (SQ3R) dalam pembelajaran kooperatif.Menurut Thabrany (2014) metode SQ3R merupakan 
metode belajar yang mempunyai tujuan agar kegiatan membaca dapat dilaksanakan sesingkat mungkin tetapi dengan daya serap yang tinggi.

\section{METODE}

Lokasi dalam penelitian ini yaitu di sekolah dasar yang ada di Kecamatan Tempe Kabupaten Wajo yakni SDN 213 Lapongkoda tahun ajaran 2018/2019. Model peneitian yang digunakan adalah penelitian tindakan kelas (classroom action research) yang meliputi empat tahap pelaksanaannya yaitu perencanaan, tindakan, observasi/evaluasi dan refleksi. Pengumpulan data dilakukan dengan teknik dokumentasi, observasi, dan tes. Teknik dokumentasi digunakan untuk merekam proses belajar mengajar berdasarkan instrumen observasi. Sedangkan tes digunakan untuk mengetahui hasil belajar. Data yang diperoleh dari hasil penelitian selanjutnya dianalisis secara kuantitatif dan kualitatif. Untuk analisis kuantitatif digunakan analisis deskriptif yang terdiri atas nilai rata-rata, nilai tertinggi, nilai terendah yang diperoleh siswa pada tes siklus. Data hasil observasi dianalisis secara kualitatif untuk melihat rata-rata dan persentase aktivitas siswa pada saat pembelajaran.

\section{TEMUAN}

Penelitian ini dilaksanakan di SDN 213 Lapongkoda Kabupaten Wajo pada siswa kelas V.B semester genap tahun pelajaran 2018/2019 dengan jumlah siswa 32 orang. dengan mengangkat materi tentang Daily Activity.

\section{Prasiklus}

Hasil tes prasiklus menunjukkan bahwa siswa yang mencapai ketuntasan nilai (nilai $\geq 75$ ) sebanyak 0 siswa atau sebesar $0 \%$ dari total 32 siswa. Sisanya sebanyak 32 siswa atau sebesar $100 \%$ dari total 32 siswa belum mencapai ketuntasan nilai (nilai< 75 ). kelemahan yang ditemukan pada siswa dalam menulis Daily Activity tahap prasiklus adalah siswa tidak bisa menuliskan aktivitas sehari-harinya sepulang sekolah dengan menggunakan bahasa Inggris, kelemahannya terdapat pada kurangnya penguasaan kosa kata.

Selanjutnya dilakukan wawancara dengan guru kelas V.B diperoleh bahwa guru mengajar dengan menggunakan model pembelajaran konvensional. Ketika pembelajaran, siswa cenderung pasif dan hanya bersifat penerima informasi. Jadi, dapat disimpulkan proses pembelajaran masih 
menggunakan model pembelajaran yang berpusat pada guru dan aktivitas sisw adalam pembelajaran masih kurang karena pembelajaran masih didominasi oleh guru.

\section{Pelaksanaan Siklus I}

Pembelajaran menulis Daily Activity pada siklus 1 terdiri dari empat tahap yaitu perencanaan, tindakan, pengamatan, dan refleksi hasil tindakan.

\section{Perencanaan}

Perencanaan pembelajaran menulis Daily Activity melalui penerapan model pembelajaran SQ3R dilakukan secara kolaboratif antara peneliti dengan guru matapelajaran bahasa Inggris kelas V SDN 213 Lapongkoda Kabupaten Wajo. Perencanaan ini meliputi:

a) Menyusun Rencana Perbaikan Pembelajaran (RPP) pokok bahasan.

b) Menyusun Lembar Kerja Siswa (LKS) pokok bahasan Daily Activity

c) Menyusun pedoman wawancara, observasi, dan dokumentasi.

Untuk mengetahui ketuntasan belajar siswa peneliti menggunakan pedoman yang digunakan oleh pihak SDN 213 Lapongkoda Kabupaten Wajosebagai berikut:

a) Daya serap perorangan, seorang siswa dikatakan tuntas jika telah mencapai nilai $\geq 75$

b) Daya serap klasikal, suatu kelas dikatakan berhasil jika terdapat minimal 65\% siswa mencapai nilai $\geq 75$

Tabel 1. Kriteria Ketuntasan Hasil Belajar Siklus 1

\begin{tabular}{|c|c|c|c|c|}
\hline \multirow{2}{*}{ Pencapaian (\%) } & \multicolumn{2}{|c|}{ Kualifikasi } & \multirow{2}{*}{ Kategori Nilai } & \multirow{2}{*}{ Tingkat Keberhasilan } \\
\hline & Angka & Huruf & & \\
\hline $80-100$ & 5 & $\mathrm{~A}$ & Baik Sekali & Berhasil \\
\hline $65-79$ & 4 & B & Baik & Berhasil \\
\hline $56-64$ & 3 & $\mathrm{C}$ & Cukup & Tidak Berhasil \\
\hline $40-55$ & 2 & $\mathrm{D}$ & Kurang & Tidak Berhasil \\
\hline $20-39$ & 1 & $\mathrm{E}$ & Gagal & Tidak Berhasil \\
\hline
\end{tabular}

Berdasarkan hasil penelitian di siklus 1 menunjukkan bahwa siswa yang mencapai ketuntasan nilai (nilai $\geq 75$ ) sebanyak 20 siswa sebesar 63\% dari total siswa 32 siswa. Sisanya sebanyak 12siswa sebesar 37\% dari 32 siswa belum mencapai ketuntasan (nilai <70). Hasiltersebut lebih baik dibandingkan dengan hasil pada tahap prasiklus, sehinggaketerampilan menulis argumentasi pada siklus I dapat dikatakan meningkat.Namun,penelitian di siklus I ini tidak berhasil atau belum tuntas karena belum mencapai standar keberhasilan secara klasikal.Hasil tersebut masuk dalam kategori nilai cukup dan tingkat keberhasilan tidak berhasil.Aspek penilaian yang masih kurang dalam Daily Activity yaitu, penggunaan kosa kata.Aspek tersebut masih banyak 
siswa yang medapat skor dibawah standar ketuntasan minimum. Oleh sebabitu, perlu adanya perbaikan dengan melaksanakan tindakan pada siklus II.

\section{Observasi}

Hasil observasi di siklus 1 yaitu terdapat beberapa aspek yang mendapat skor kurang diantaranya guru kurang mengaitkan materi dengan pengetahuan lainyang relevan dan kurang menunjukkan hubungan antar pribadi yang kondusif.Dengan demikian, diperlukan perbaikan pada siklus II untuk mencapai hasil yang lebih sempurna.Sedangkan untuk melihat kriteria keefektifan model pembelajaran SQ3R di siklus 1 adalah sebagai berikut:

\section{Tabel 2. Kriteria Penilaian Keefektifan Model Pembelajaran SQ3R Siklus I}

\begin{tabular}{ccccc}
\hline \multirow{2}{*}{ Pencapaian $(\%)$} & \multicolumn{2}{c}{ Kualifikasi } & \multirow{2}{*}{ Kategori Nilai } & \multirow{2}{*}{ Tingkat Keberhasilan } \\
\cline { 2 - 3 } & Angka & Huruf & & Baik Sekali \\
\hline $80-100$ & 5 & A & Berhasil \\
$65-79$ & 4 & B & Baik & Berhasil \\
$56-64$ & 3 & C & Cukup & Tidak Berhasil \\
$40-55$ & 2 & D & Kurang & Tidak Berhasil \\
$20-39$ & 1 & E & Gagal & Tidak Berhasil \\
\hline
\end{tabular}

Berdasarkan hasil penelitian diperoleh datapersentase proses pembelajaran dengan menggunakan metode SQ3R sebesar 66\%.Hal ini berarti proses pembelajaran dengan menggunakan metode SQ3R termasuk pada kriteria baik.Akan tetapi, siswa masih kurang dalam komponen pemecahan masalah dalam kelompok. Hal ini terjadi karena siswa merasa malu, takut untuk berbagi atau menyunting hasil kerja teman sebaya, dan masih bingung cara menyunting yang benar. Dengan begitu, diperlukan perbaikan pada siklus II.

\section{Refleksi}

Kegiatan rekleksi dilakukan peneliti dan guru kelas setelah proses pembelajaran. Berdasarkan hasil penugasan, observasi, dan wawancara pada siklus I diketahui bahwa terdapat peningkatan aktivitas belajar siswa dibandingkan sebelum tindakan.Namun, penelitian di siklus I ini masih perlu ditingkatkan lagi untuk menyempurnakan pembelajaran dengan menggunakan model SQ3R untuk meningkatkan keterampilan menulis Daily Activity. 


\section{Pelaksanaan Siklus II}

Siklus II merupakan upaya perbaikan berdasarkan hasil analisis pada siklus I.

\section{Perencanaan}

1) Menyusun Rencana Perbaikan Pembelajaran (RPP) pokok bahasan Daily Activity.

Rencana Perbaikan Pembelajaran (RPP) disusun untuk 1 kali pertemuan pada siklus II

2) Menyusun Lembar Kerja Siswa (LKS) pokok bahasan menulis Daily Activity.

\section{Tindakan Siklus II}

Guru membagi siswa dalam beberapa kelompok, setiap kelompok terdiri dari empat siswa. Untuk setiap kelompok, guru membebaskan siswa memilih sendiri.Setelah siswa duduk dalam kelompok masing-masing guru membagikan LKS dan memerintah siswa untuk menulis kembali Daily Activity dengan tema yang berbeda di siklus I .Dalam kegiatan siklus II ini guru juga turut membimbing siswa jika ada siswa yangbertanya tentang materi.Berikut ini hasil menulis Daily Activity siswa SDN 213 Lapongkoda Kabupaten Wajo siklus II.Hasil penelitian menunjukkan bahwa siswa yang mencapai ketuntasan nilai (nilai $\geq 75$ ) sebanyak 28 siswa atau sebesar $88 \%$ dari total 32 siswa. Sisanya sebanyak 4 siswa atau sebesar $12 \%$ dari total 32 siswa belum mencapai ketuntasan nilai (nilai< $<5$ ).

Aspek penilaian menulis Daily Activity yang mengalami peningkatan. Oleh sebab itu bisa dikatakan penelitian pada siklus II ini sudah mencapai standart ketuntasan minimal klasikal, sehingga tidak perlu dilaksanakan perbaikan lagi.

\section{Observasi}

Berdasarkan data dari tabel observasi guru dan siswa dalam pelaksanaan pembelajaran, diperoleh data persentase aktivitas guru adalah 96\% dan siswa 97\%.Hal ini berarti aktivitas guru masuk pada kriteria nilai berhasil atau baik sekali dan aktivitas siswa masuk pada kriteria nilai berhasil atau baik sekali.Hasil tersebut lebih baik dibandingkan dengan hasil pada tahap siklus I, sehingga keterampilan menulis Daily Activity pada siklus II dapat dikatakan meningkat.Sesuai dengan criteria ketuntasan, persentase aktivitas guru dan keaktifan siswa tersebut dikatakan sudah mencapai ketuntasan belajar secara klasikal yaitu 96\% dan 97\%.

\section{Refleksi}

Pembelajaran siklus II yang telah dilakukan sudah sesuai dengan standarketuntasan yang telah direncanakan. berdasarkan hasil analisis ketuntasan belajarpada siklus II yang menunjukkan 
bahwa siswa yang mengikuti post-test dengan jumlah 32 siswa yang tuntas secara perorangan sejumlah 28 siswa dan siswayang tidak tuntas secara perorangan sebanyak 4 siswa. Persentase ketuntasan hasilbelajar melalui metode inkuiri pada siklus II sebesar 88\%.Peningkatan tersebut terjadi karena hasil tulisan siswa sudah dapat menunjukkan bukti penunjang dan organisasi karangan dengan baik.

Suasana pembelajaran di kelas juga semakin kondusif dan aktif sesuai dengan rencana yang telah dibuat. Keaktifan guru semakin tampak dibandingkan siklus I dengan persentase sebesar 96\%.Tingkat keaktifan siswa juga semakin merata bila dibandingkan dengan pembelajaran siklus I. Sesuai dengan kriteria keberhasilan,persentase tersebut dikatakan sudah mencapai ketuntasan belajar secara klasikal yaitu97\%. Begitu juga proses pembelajaran menggunakan metode SQ3R semakin meningkat dengan persentase 97\%. Berdasarkan data di atas, persentase observasi sudah maksimal dan ketuntasan belajar sudah memenuhi standar ketuntasan klasikal,maka penelitian dapat dihentikan. Bagi 4 siswa yang belum mencapai criteria ketuntasan minimal (KKM) akan diberikan bimbingan individu. Kekurangan yangterjadi di siklus I sudah dapat teratasi pada siklus II.

\section{DISKUSI}

\section{Ketuntasan Hasil Belajar Siswa}

Penelitian ini menggunakan Penelitian Tindakan Kelas (PTK) yang bertujuan untuk meningkatkan aktivitas dan hasil belajar. Penelitian Tindakan Kelas (PTK) merupakan suatu pencermatan terhadap kegiatan belajar berupa sebuah tindakan, yang sengaja dimunculkan dan terjadi dalam sebuah kelas secara bersama (Suharsimi, dkk, 2006:3).

Berdasarkan hasil analisis selama pembelajaran menggunakan metode SQ3R diperoleh data perbandingan setiap siklus.Data perbandingan setiap siklus dapat dilihat pada tabel berikut.

\section{Tabel 3. Hasil Perbandingan Menulis Daily Activity Persiklus}

\begin{tabular}{ccccccccc}
\hline \multirow{2}{*}{ No } & \multirow{2}{*}{$\begin{array}{c}\text { Perolehan } \\
\text { Nilai }\end{array}$} & $\begin{array}{c}\text { Jumlah } \\
\text { Siswa }\end{array}$ & Presentase & $\begin{array}{c}\text { Jumlah } \\
\text { Siswa }\end{array}$ & Presentase & $\begin{array}{c}\text { Jumlah } \\
\text { Siswa }\end{array}$ & Presentase & Ket \\
\hline 1 & Nilai $\geq 75$ & 0 & $0 \%$ & 20 & $63 \%$ & 28 & $88 \%$ & T \\
2 & Nilai $<75$ & 32 & $100 \%$ & 12 & $37 \%$ & 4 & $12 \%$ & TT \\
& Jumlah & 32 & $100 \%$ & 32 & $100 \%$ & 32 & $100 \%$ & \\
\hline
\end{tabular}

Berdasarkan tabel di atas, pembelajaran bahasa Inggris dengan menggunakan metode SQ3R mengalami peningkatan dari siklus ke siklus berikutnya. Berdasarkan hasil penelitian dapat dilihat bahwa tahap prasiklus siswa yang mendapat nilai $\geq 75$ (tuntas) sebanyak 0 siswa $(0 \%)$, sedangkan siswa yangmendapat nilai $<75$ (tidak tuntas)sebanyak 32 siswa (100\%). Pada siklus I setelah diterapkan metode SQ3R dalam pembelajaran menulis Daily Activity terjadi peningkatan 
hasil belajar. Siswa yang mendapat nilai $\geq 75$ (tuntas) sebanyak 20 siswa(63\%) dan yang belum mencapai ketuntasan hasil belajar berkurang menjadi 12 siswa(37\%) Pada siklus II juga menerapkan metode SQ3R dalam pembelajaran menulis Daily Activity yang direncanakan lebih cermat dan disempurnakan sehingga hasil yang didapat lebih baik dan mengalami peningkatan dari siklus sebelumnya.Hasilnya siswa yang mendapat nilai $\geq 75$ (tuntas) sebanyak 28 siswa (88\%),sedangkan yang belum mencapai ketuntasan sebanyak 4 siswa (12\%)

Uraian tersebut menunjukkan bahwa antara prasiklus ke siklus I terjadi peningkatan sebanyak 20 siswa.Demikian juga antara siklus I ke siklus II juga mengalami peningkatan sebanyak 8 siswa.Berdasarkan hasil tersebut maka ketuntasan belajar secara klasikal telah tuntas karena telah mencapai $88 \%$ dimana standar ketuntasan minimum secara klasikal adalah 80\%.Dengan demikian dapat disimpulkan bahwa keterampilan menulis Daily Activity dapat meningkat setelah diterapkan pembelajaran dengan menggunakan metode SQ3R.

\section{Aktivitas Guru dan Siswa dalam Pembelajaran}

Aktivitas guru dalam pelaksanaan pembelajaran menulis Daily Activity dalam penelitian ini dikatakan baik pada siklus I dengan persentase $84 \%$ dan dikatakan baik sekali, pada siklus II dengan persentase 96\%. Guru menguasai materipelajaran, memberikan motivasi, mengaitkan materi dengan pengetahuan yangrelevan, guru mengaitkan materi argumentasi dengan media pembelajaran.

Aktivitas siswa terdapat dua macam yaitu proses pembelajaran metode SQ3R dan keaktifan siswa. Kegiatan pembelajaran melalui metode SQ3R membuat siswa kreatif, memecahkan masalah dengan teman sebaya, dan termotivasi dalam pembelajaran menulis Daily Activity. Proses pembelajaran metode SQ3R sudah baik dengan persentase proses pembelajaran metode SQ3R 66\% pada siklus I dan 97\% pada siklus II. Dalam proses pembelajaran metode SQ3R ini, siswa sangat serius dan aktif dalam tahap Sebaya, Media, Aplikasi, Remidi,dan Tes sehingga terlihat peningkatan pada siklus II. Ketertiban dan keaktifan siswa juga sangat baik.Pada siklus I persentase keaktifan siswa 69\% dan pada siklus II 97\%.

\section{Tabel 4. Persentase aktifitas guru dan siswa dalam proses pembelajaran}

\begin{tabular}{|c|c|c|c|c|}
\hline No. & Tindakan & $\begin{array}{l}\text { Keaktifan } \\
\text { Guru }(\%)\end{array}$ & $\begin{array}{c}\text { Keaktifan Siswa } \\
(\%)\end{array}$ & $\begin{array}{c}\text { Proses } \\
\text { Pembelajaran }(\%)\end{array}$ \\
\hline $\begin{array}{l}1 . \\
2 .\end{array}$ & $\begin{array}{l}\text { Siklus I } \\
\text { Siklus II }\end{array}$ & $\begin{array}{l}84 \% \\
96 \%\end{array}$ & $\begin{array}{c}\text { Aktif }=69 \% \\
\text { Kurang aktif }=31 \% \\
\text { Aktif }=97 \% \\
\text { Kurang Aktif }=4 \%\end{array}$ & $\begin{array}{c}\text { Aktif }=66 \% \\
\text { Kurang aktif }=34 \% \\
\text { Aktif }=97 \% \\
\text { Kurang Aktif }=3 \%\end{array}$ \\
\hline
\end{tabular}




\section{SIMPULAN}

1. Penerapan Model pembelajaran SQ3R dalam pembelajaran bahasa Inggris khususnya materi menulis Daily Activity dapat meningkatkan kemampuan siswa. Hal ini bisa dilihat dari hasil menulis siswa yang semakin meningkat baik dari siklus I sampai pada siklus II. Siswa menjadi kreatif, aktif, dan percaya diri. Hal ini disebabkan adanya penggalian kemampuan siswa melalui model pembelajaran yang diterapkan. Siswa juga lebih mudah dalam menuangkan idenya sehingga pendapat mereka dapat tersalurkan.

2. Hasil belajar menulis Daily Activity setelah diterapkan model pembelajaran SQ3R pada siswa kelas V SDN 213 Lapongkoda Kabupaten Wajo mengalami peningkatan. Pada Prasiklus ketuntasan hasil belajar siswa $0 \%$, pada siklus I meningkat 63\%, danpada siklus II juga meningkat 88\% sehingga secara klasikal memenuhi criteria ketuntasan Minimal (KKM). Hal ini ditunjang dengan keaktifan guru yang meningkat dari 84\% menjadi 96\%.

\section{REFERENSI}

Anni, Catharina Tri, dkk. 2014. Psikologi Belajar. Semarang: UPT MKK UNNES Press

Aqib, Zainal. 2016. Penelitian Tindakan Kelas. Bandung: CV Yrama Widaya

Arikunto, Suharsimi, Suhardjono, dan Supardi. 2014. Penelitian Tindakan Kelas. Jakarta: PT Bumi Aksara.

Lie, Ananta. 2014. Cooperative Learning, Mempraktikkan Cooperative Learning di Ruang-ruang Kelas. Jakarta: PT Grasindo.

Mulyasa.2016. Kurikulum Tingkat Satuan pendidikan. Bandung: Rosda Karya.

Nurhadi. 2015. Kurikulum 2004 (Pertanyaan dan Jawaban) Jakarta: PT Grasindo.

Priatiningsih, Titi. 2004. Pengembangan Instrumen Penelitian Biologi. Semarang: Dinas Pendidikan dan Kebudayaan Jawa Tengah.

Qiao Mingdao and Jin Xiaoling. 2010. "Jigsaw Strategy as a Cooperative Learning Technique: Focusing on The Langage Learner" In Chinese Journal of Applied Linguistics Available at www.celea.org.en/teic/92/pdf diakses tanggal 7 April 2018

Slameto. 2013. Belajar dan Faktor-faktor yang Mempengarubinya. Jakarta: PT Rinneka Cipta.

Solihatin, Etin dan Raharjo. 2017. Cooperative Learning, Analisis Model Pembelajaran IPS. Jakarta: PT Bumi Aksara.

Sudaryo, dkk.2011.Strategi Belajar Mengajar 1. Semarang: IKIP Semarang Press. 
Sudjana, Nana. 2005. Penilaian Hasil Proses Belajar Mengajar. Bandung: Remaja Rosda Karya.

Suharta.,\& Luthan, Putri Lynna A. 2013. Application of Cooperative Problem-Based Learning Model to Develop Creativity and Foster Democracy, and Improve Student Learning Outcomes in Chemistry in High School.Journal of Education and Practice, 4 (25), 55-60.

Sujadi, E. (2017). Penerapan Pendidikan Karakter Cerdas Format Kelompok Untuk Meningkatkan Nilai Kejujuran Mahasiswa Bimbingan Konseling Islam (BKI) Institut Agama Islam Negeri (IAIN) Kerinci. Tarbawi : Jurnal Ilmu Pendidikan, 13 (1), 97-108

Sujadi, Eko., Ayumi, Rinda Tri., Indra, Syaiful., Sumarto., Rahima, Raja. 2018). Layanan Konseling Kelompok dengan Menggunakan Pendekatan Cognitive Behavioral untuk Membentuk Internal Locus of Control. Jurnal Fokus Konseling, 4 (2): 176-184.

Syah, Muhibin. 2016. Psikologi Pendidikan dengan Pendekatan Baru. Bandung: PT Remaja Rosdakarya.

Thabrany, Hasbullah. 2014. Rahasia Sukses belajar. Jakarta: PT Raja Grafindo Persada.

Tsay, Mina and Brady, Miranda.2010 "A case study of cooperative learning and communication pedagogy" in Journal of the scholarship of Teaching and Learning.Vol 10, No 2.Available at http:/ www.iupul.edu/josotl diakses 14 Juli 2018.

Uno, Hamzah B. 2016. Perencanaan Pembelajaran. Jakarta: PT Bumi Akasara

Yamin, Martinis. 2015. Strategi Pembelajaran Berbasis Kompetensi. Jakarta: Gaung Persada Press 